\title{
International Human Resource Management Practices in Automotive Industry in Pakistan: Implications for Economic Growth
}

\author{
Muhammad Ahmed Butt ${ }^{1} \&$ Paul Katuse ${ }^{1}$ \\ ${ }^{1}$ United States International University-Africa, Nairobi, Kenya \\ Correspondence: Muhammad Ahmed Butt, Doctor of Business Administration (Candidate), United States \\ International University-Africa, P.O.Box 14634-00800. Nairobi, Kenya. E-mail: info@usiu.ac.ke
}

Received: December 6, 2016

Accepted: January 20, 2017

Online Published: January 26, 2017

doi:10.5539/ijbm.v12n2p136

URL: http://dx.doi.org/10.5539/ijbm.v12n2p136

\begin{abstract}
The purpose of this article is to examine the drivers of global standardization and localization of International Human Resource Management (IHRM) practices internalized by Pakistan's automotive industry leading to sustainable economic growth. The authors have studied the IHRM determinants influencing the automotive manufacturers, and have assessed its impact on sustainable economic growth. Analysis is developed on the antecedent IHRM theories and literature in the backdrop of Pakistan's automotive industry. The study highlights the paramount aims of host-country IHRM practices viz global standardization and localization, its impact on host-country organization's performance and resultant effect on sustainable economic growth. The article has focused, in subtle manner, on improving the explicit understanding on IHRM practices viz global standardization and localization drivers to achieve both growth for the industry and sustainable economic development of the country. The study is based on already generated literature thereby limiting the generalizability thereof, and provides a review of IHRM practices and outcomes in automobile sector in the growth context. The results have presented guidelines to researchers and practitioners doing research in human side in automotive industry providing impetus for growth, both at industry and country level.
\end{abstract}

Keywords: international human resource management, global standardization, localization, sustainable growth

\section{Introduction}

In line with the World Investment Report issued by United Nations in 2006, there are currently 77,000 transnational corporations having 770,000 foreign affiliations, gainfully employing 62 million workforces globally. This is one of the critical facets that underpin the frontiers of globalization and its businesses spheres. With this spiral hike in the scale and degree of transnational/global operations, the role of human resource management in sustaining this increase in international businesses activities is a central theme which international human resource management(IHRM) addresses(Dowling et al., 2013). Morgan (1986) presents IHRM in three dimensions and defines international HRM as the interplay among those three dimensions i.e. human resource activity, types of employees, and countries of operations.

The purpose of this article remains squarely focused on examining the IHRM drivers of globalization and localization in host-country, keeping Pakistan's automotive sector as a central case, and determining its effect on automotive industry players; its cascaded impact on manufacturing sector's growth and Pakistan's economic development, in macro perspective. The article presents an overview in comprehensive terms, in the form of survey and synthesis, encompassing the full spectrum of literature on international HRM, its critical determinants (i.e. globalization and localization in host-country context), its implications for automotive industry, and sustainable economic growth of the host country, an enormous activity that has consumed considerable effort, enough to generate several review papers. Nevertheless the key objective of this study is to deliberate and discuss the components of IHRM practices in host-country in the context of both automotive sector, and economic growth of Pakistan.

\section{International HRM}

Consistent with the thoughts of scholars, the importance of human resources is explicit and acknowledged; linking it with organizational output and economic indicators of Gross Domestic Product (GDP) provided impetus to augment IHRM research (Sparrow\& Marchington, 1998; Legge, 2004). One of the ways to create 
distinction among IHRM academics is to make a group of those researchers undertaking studies in HRM processes in global firms, and not placing emphasis on social and cultural issues as against the other set of academics, stressing on broader perspective inclusive of social and cultural components (Beardwell \& Holden, 2001). The former group sought to give due consideration to the role of international manager, and global HR systems (Scullion, H. 2001). The latter group is diverse in nature and captured the context of comparative facets especially international and comparative employment and industrial relations systems (Brewster et al., 2004; Edwards \& Almond 2005). IHRM studies are concerned with HR issues on global canvas that are 'unfolding' with the 'various stages of the internationalization process' (Boxall, 1995). When Boxall (1995) made this statement, IHRM research and scholarship were at its early stage of growth. From that point onwards, the discipline of IHRM transformed itself to an area of importance for academic expertise.

\subsection{Theory of IHRM}

One area of academic work, focused by human resource management (HRM) scholars, is making efforts to uncover HRM best practices approach linked with specific human resource (HR) strategic interventions regardless of societal and industrial sectors' contexts (Sparrow\& Marchington, 1998; Legge, 2004). Whilst there is explicit evidence that HR practices can yield higher productivity and augment organizational performance (Huselid, 1995; Kiessling \& Harvey, 2005), HRM may be an universalistic strategy, and in mid-1990s, this point of reasoning appeared to influence much international business thinking (Boxall, 1995).

HRM seems to be more of a theoretical construct than an applied reality (Pieper1990, Legge, 2004). The diagnosing of the rhetoric vis-à-vis the reality of HRM emerged as a field of investigation (Rees et al., 2005). However, evidence suggests that globalization is effecting a universalistic approach (Marquardt \&Berger, 2003).The performance model has influenced IHRM theorizing and it has communicated an issue for greater societal well-being (Boxall, 1995; Sparrow \& Marchington, 1998). The international HRM (IHRM) literature has traditionally focused on multinational corporations (MNCs) as a 'head-office' driven entity, and constructs choices as a function of environmental issues for analysis and strategic interpretation by central MNCs executives (Ngo et al., 1998).

\subsection{Theoretical Perspective of Standardization and Localization}

Possessing prior internationalization experience; such as the partners who have worked through and practiced their HRM approaches in other environments, have both, a basis for expecting successful implementation of standardized, isomorphic HR practices, and a negotiation history to support it, consistent with expectations at an individual level (Carpenter et al., 2001). This is akin to Lambe et al., (2002) articulation of 'alliance competence'; embedding of HRM practices in production systems (Meardi, 2004; Kubo \& Saka, 2002), thus requiring operational consistency among practices in order to guarantee operational effectiveness and efficiency, and full utilization of the transfer of technology and expertise (Kostova \& Zaheer, 1999)

Competing demands of global integration and local differentiation have highlighted the need to develop human resources as a source of competitive advantage (Caligiuri \&Stroh 1995; Sehuler et at., 1993; Taylor et al., 1996), MNCs standardization and local practices. In the context of international business, a number of scholars have pointed to the choice that MNCs typically must make between either standardizing their policies and practices across global settings or adopting local practices (Prahalad \& Doz, 1987). Rosenzweig \& Nohria (1994) noted that when an HRM practitioner adhered to local practices (the US), the achievement was at 'the expense of similarity to parent country practices', and this 'expense' varied across different HRM practices. As MNCs and their international subsidiaries have become increasingly important players in the global economy, interest in, and research on the strategies and management practices of these firms have advanced apace. Within this literature, one significant line of enquiry relates to the capacity of the MNCs to achieve international integration in its policies and practices (Kim et al., 2003). As Smale et al., (2013) note "what is lacking, however, is systematic research that combines multiple mechanisms of global HRM integration and explanations behind their reportedly differential usage". Smale et al., (2013) work constitutes a calling to undertake a specific examination of how different integration mechanisms are used across a range of HRM practices encompassing employee reward, development and relations. Building on Kim et al., (2003) four way classification of modes of integration (centralization, formalization, information and people based), and responding to the call by Smale et al., (2013) an analysis develops of the differentiated use of these integration modes across a suite of different HRM practices (pay and rewards, performance appraisal systems, training and development, employee involvement and industrial relations).

The debate on international integration and local adaptation of practices has attracted considerable attention, particularly in recent years (Gunnigle et al., 2002; Pudelko, M. 2006; Almond \& Ferner, 2006; Ferner et al., 2011; 
Mayrhofer et al., 2011; Bélanger et al., 2013; Smale et al., 2013). According to Smale et al., (2013) MNCs make efforts to control the HRM policies and practices of their subsidiaries. And do try to ensure coordination of the policies and practices across their subsidiaries. Cray (1984) postulated that international integration occurs through two distinct processes, namely, control and coordination. Control and coordination are therefore seen as the two primary undertakings of global integration (Cray, 1984; Martinez \& Jarillo, 1991; Kim et al., 2003). As Kim et al., (2003) note, "global integration becomes possible only through the use of organizational mechanisms for coordination and control".

\section{Global Standardization and Localization}

Dowling et al., (2013) aptly stated that effective multinational managers do require to be sensitive, to follow and adapt to the host-country requirement and systems relating to HR practices and accord respect to local cultures and host-country situations; and that mismatch results in dysfunction effect on both the parent company as well as the subsidiaries in foreign locations. Corporate strategy, goals and objectives are propelled by strategic resources orientation of the organization. As Harzing (1999) affirms; there exists a continuum of advantages for both standardization and localization. Figure 1 depicts the factors of global standardization and localization.

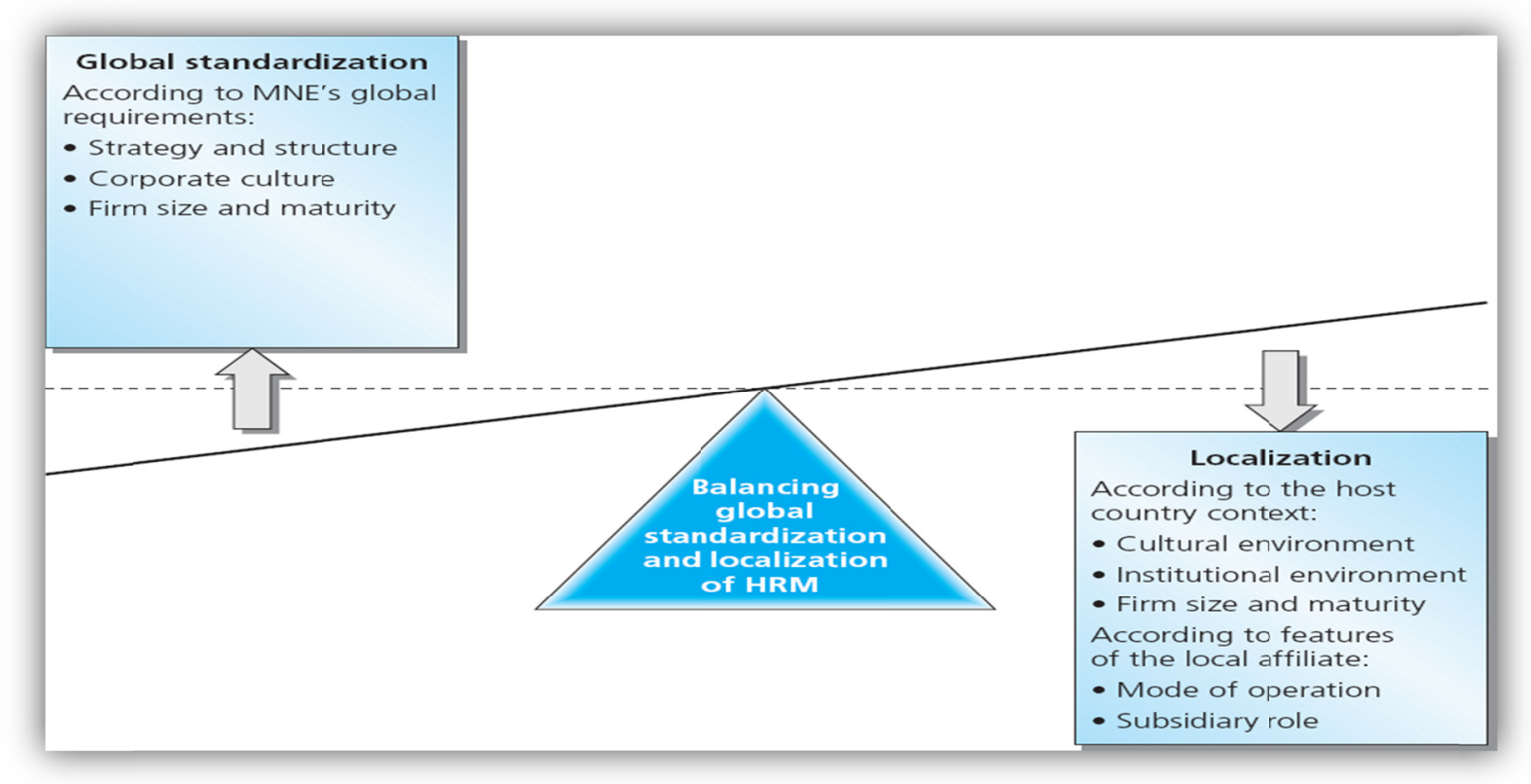

Figure 1. The factors of global standardization and localization

Source: Festing, M., Eidems, J. \& Royer, S. (2007).

\subsection{Determinants Driving Standardization}

Festing et al., (2007) presented a model of standardization and localization of human resource management in multinational corporations (MNCs). Determinants of global standardization are; (1) strategic issues including corporate strategy. Taylor; Beehler, and Napier (1996) argued that there is reciprocal relationship between organizational factors, strategic HRM, and MNCs' goals and strategy. Structure of the organization and its impact on HRM(Nohria \& Ghosal,1997) focuses on the capability of networking structure of subsidiaries to package (slack resources) to stimulate 'local-for-local' 'local-for-global 'and 'global-for-global' innovation process; (2) consideration for corporate culture regards HRM activities as important culture identity (Alvesson \& Berg, 1992). Some global firms have become more systematic in their efforts to achieve control by way of shared corporate culture; these efforts have become central point in IHRM strategy (Dowling et al., 2013).The point (3) is firm's size and maturity in degree of international experience (Myloni, Harzing \& Mirza 2007). These factors are dependent upon each other. In practice, nevertheless, perfect adherence to these factors in all Multinational Enterprises (MNEs) is not observed (Dowling et al., 2013).

\subsection{Determinants Driving Localization}

The (1) factor compelling localization is cultural environment of the host-country. Sparrow et al., (2004) identified cultural influence on reward behavior such as in the manager-subordinate relationship, different 
expectations of the two and their influence on performance management and motivation process. Hofstede (1980) studies have made important contribution toward the body of knowledge in understanding the cultural differences in organizational context. The (2) driver for localization is host-country institutions and their setting which shapes the behavior and expectation in subsidiaries (Scott, 1995). Institutional norms may be based on the features of a national business system i.e. educational system or the industrial relations system (Whitley 1992). Khilji (2002) rightly asserted that although foreign multinational in Pakistan have formulated policies, implementation is low, because managers brought up and trained in hierarchical and centralized set-up resist sharing power and involving employees in decision-making. This occurred despite the host-country's expectation that MNCs would transfer their best practices. Khilji (2002) pointed out in the study and has observed a polycentric approach in host-country nations (HCNs) in the key position including that of HR Manager. Sometime reverse diffusion i.e. transfer of practices from foreign locations to headquarters can be witnessed (Edwards et al., 2005). This facet of reverse diffusion is captured in Figure 2.

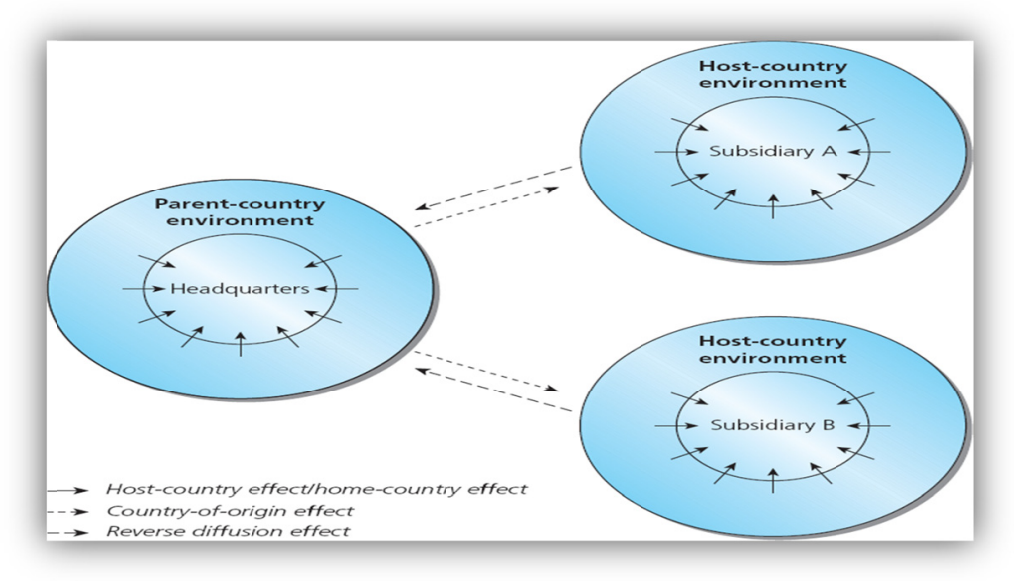

Figure 2. The facet of reverse diffusion

Source: Dowling, P., Marrion, F. \& Engle, A. (2013).

The (3) driver is mode of operation abroad. A study by Buckley et al., (2003) presented two examples of how the mode of operation either inhibits or facilitates work standardization. China government in late 1978 promoted open door policy and efforts were made for transition from centrally planned to market economy. Western organizations that entered in the beginning were by and large forced to enter into joint ventures with state-owned enterprises (SOEs), whereas those entering late had the choice to be wholly owned subsidiaries (WOSs). Ownership and control are therefore important factors that need to be taken into consideration when MNCs attempt to standardize work and HRM practices; firm's ability to independently implement processes and procedures is naturally higher in WOEs whilst the question of control in International Joint Venture(IJV) remains a concern for multinational firms(Dowling et al.,2013). The (4) determinant of localization is subsidiary role. Gupta \&Govindarajan (1991) provided generic subsidiary roles, namely global innovators, integrated players, implementers, and local innovators. Mikhailovich \& Husted (2003) used the terms 'knowledge-sharing hostility' and 'knowledge hoarding' non-sharing behavior identified in their study of firms operating in Russia. Birkinshaw \& Ridderstrale (1999) defined the structural power and resources based power of subsidiaries vis-à-vis the corporate headquarters as two basic sources of influence within networks and distinguished between 'core' subsidiaries and 'peripheral' subsidiaries. This discussion has portrayed the fact that the role of subsidiary and transfer of knowledge may influence the balance of standardization and localization (Dowling et al., 2013)

\section{Economic Effect}

Economic growth is one of the most important notions in the global economy. Despite the criticism that the level and rate of growth does not always reflect the real level of a population's living standards, it remains the primary measure of prosperity (Pietak, 2014). Sen (1999) aptly describes economic growth as determinant means for enhancing the substantive freedoms that are valued by people. These freedoms are importantly linked with improvements in living standards, i.e. more opportunities for masses, to eat well, be healthier and live longer. Pakistan's economy reflects consistent improvement, Gross Domestic Product (GDP) growth was documented at 4.24 percent in 2014-15 vis-à-vis the growth of 4.03 percent in the previous year. The targeted growth rate of 5.1 
percent could not be realized due to various constraints both exogenous and endogenous. The government designed economic policies aimed at augmenting the holistic business climate and organizational support, and planned conducive strategic moves to create an environment to capitalize on resources and optimize the potential of the economy. Manufacturing is the major driver of industrial sector's growth. This sector has 65.4 percent meaningful impetus in the overall industrial sector. In terms of GDP, its impact is 13.3 percent. Automotive sector documented 17.02 percent growth in 2015 as against 0.35 percent in 2014 (Ministry of Finance, Pakistan,2015).To capture the economic strength the per capita income indicator is critical to help determine the state of economic development of the country. The per capita income in dollar terms increased from $\$ 1,384$ in 2013-14 to \$1,512 in 2014-15 (Ministry of Finance, Pakistan, 2015).

\subsection{Automotive Industry}

Automotive manufacturing industry players have internalized various approaches of work management over the years; from the Fordist method in which the workforce performed manual work in terms of continuous assembly-line jobs (Lewchuk \& Robertson, 1997; Dohse et al., 1985), to internalizing of Japanese models, stressing workers engagement and substantial intellectual impetus (Klein, 1991; Dohse et al., 1985). The focus on increased productivity and competitiveness is one feature that the adopters have unmistakably shared.

In 2015, Pakistan's automotive industry documented contribution of 17.02 percent toward the manufacturing sector, producing around 822 thousand units; by 2019 the number of forecasted units will increase to 1,329 thousands (Engineering Development Board, Government of Pakistan, 2016). In terms of market value, it is estimated to reach $\$ 2.9$ billion by 2019 . And substantial employment is generated directly and indirectly in this sector (around 1.5 million).This phenomenon has reasonable impact on the economy of the Pakistan. The industry has backward and forward linkages responsible to create economic activity and generate employment in downstream industries. Greater emphasis has been placed by governing bodies, industry players and researchers on the technical side and on fostering the automotive sector's growth through technological improvements and managing this industry (Ministry of Industries \& Production, 2016). Ironically, there is very little research or academic work seen in the literature regarding human side particularly from the perspective of IHRM practices in automotive industry of Pakistan.

\section{Discussion}

Globalization has brought in its wake significant extrinsic and mammoth intrinsic changes for transnational corporations with significant impact on all the facets of organization's working inclusive of the fact that around 62 million people are productively linked with transnational organizations worldwide (United Nations report, 2006). With growing significance of global economic integration and increased share of multinational firms in global economy, IHRM has gained center stage, in particular, dealing with human side of the organization in the global work management operations across various regions, and countries of the world to realize leading competitive edge (Dowling et al., 2013). Whereas Morgan (1986) noted that IHRM has three critical dimensions, namely; human resource activity, types of employees, and countries of operations. Dowling et al., (2013) maintained the argument that the underlying factor to be borne in mind is that diversity as managed within single nation context may not necessarily transfer to multinational context without some modification. Scholars like (Sparrow et al.,2004; Legge, 2004) have validated this point that giving adequate importance to human resources in the organizations results in increased productivity and creates domino effect on national domestic product (GDP) of the country.

Boxall (1995) reiterated that IHRM studies are focused on HR facets in the global perspective and that unfold consistent with various phases of the internationalization process. This argument of (Boxall, 1995) served as catalyst in the evolution of IHRM discipline from its embryonic stage to an era of importance for research scholars and academic experts. Different scholars advocated different points of view with varied significance. For instance, for Pieper (1990) and Legge (2004) human resource management seems to be more of a theoretical construct than an applied reality. The examining of the rhetoric vis-à-vis the reality of HRM emerged as a field of investigation (Rees et al., 2005). Nevertheless, evidence captures the fact that globalization is effecting a universalistic approach (Marquardt \&Berger, 2003). Multinational organizations are faced with dilemma; whether to opt for global standardizations or localization. The competing and strategic demands of global integration and local differentiation have highlighted the need to develop human resources as a source of competitive advantage (Caligiuri \& Stroll, 1995; Sehuler et at., 1993).

Regarding production operations of MNCs in the global arena, embedding of HRM practices in production systems (Meardi, 2004; Kuba \& Saka, 2002), full utilization of the transfer of technology and expertise, guaranteed effectiveness in the organization (Kostova \& Zaheer, 1999). Effective multinational management 
requires to be sensitive to follow and adapt to the host-country's local cultures and institutions (Dowling et al., 2013); mismatch results in dysfunction effect both on parent country and foreign locations. To support this argument, Harzing (1999) mentions that there exists a continuum of advantages for both standardization and localization for MNCs.

Determinants of global standardization, according to Festing et al., (2007) are; firstly, strategic issues including corporate strategy, secondly consideration for corporate culture regards HRM activities as important cultural identity (Alvesson \& Berg 1992), thirdly, size of the firm and maturity in terms of international experience (Myloni, Harzing \& Mirza 2007 ). These drivers of global standardization are interdependent and their interplay is imperative. In reality, nonetheless, perfect adherence to these factors in all MNEs is not observed (Dowling et al., 2013).

From among the compelling drivers of localization, first is cultural environment of the host-country (Sparrow et al., 2004). Hofstede (1980) studies have made important contribution toward knowledge in understanding the cultural differences in organizational context. The second driver concerning localization is that of host-country institutions which shape the behavior and expectation in subsidiaries (Scott, 1995). The third and fourth factors of localization include mode of operation abroad, and subsidiary role. Khilji (2002) aptly observed that although foreign multinationals in Pakistan have formulated policies, implementation is low; reason being that managers brought up and trained in hierarchical and centralized set-up resist sharing power and involving employees in decision-making. Dowling et al., (2013) believe that the role of subsidiary and transfer of knowledge may influence the balance of standardization and localization.

In global economy, the notion of economic growth is of paramount importance. Notwithstanding the critique that rate of growth does not always capture the real level of a population's living standards, it remains the primary determinant of prosperity (Pietak, 2014). Pakistan's economy reflects consistent improvement; GDP growth was documented at 4.24 percent in 2014-15. The per capita income in dollar terms has documented at $\$ 1,512$ in 2014-15 which is higher by US\$ 129 than the previous year (Ministry of Finance, Pakistan). Manufacturing is the focal driver for industrial sector's growth. Automotive manufacturers have internalized various approaches of work management over the years. In Fordist method the workforce primarily had manual tasks in terms of repetitive assembly-line Jobs (Lewchuk \& Robertson, 1997, Dohse et al., 1985).With the advent of Japanese auto manufacturers, business model gradually underwent change and new technologies and practices were adopted. The sector has grown and is significantly contributing toward employment generation, industrial growth and economic development of the country. In 2015, Pakistan's automotive sector documented contribution of 17.02 percent to the manufacturing sector, producing around 822 thousand units. In terms of market value it is estimated to reach $\$ 2.9$ billion by 2019 . Around 1.5 million workforce is gainfully employed in automotive industry. Impetus provided by this sector to the economy of the Pakistan cannot be overemphasized. Ministry of Industries \& Production, Pakistan has its focus on fostering the industry from technical and operationalization context, however developing the literature regarding human side of IHRM practices in automotive industry in Pakistan has been undermined.

\section{Conclusion}

The global multinational corporations have to resolve the idiosyncrasies underpinning the strategic move to standardize globally or to proceed with localization of IHRM practices in a country like Pakistan. Khilji (2002) study established the fact that polycentric orientation seems ostensible in multinational corporations having operations in the country and automotive industry is no exception. Challenges confronted by foreign-based organizations in host-country like Pakistan to establish global standardization in IHRM is inhibited by strong gravitation of localization factors. There is dearth of literature and studies having underlying themes related to human side of work management in the key automotive industry in Pakistan. Considering the views of Dowling et al., (2013) the role of subsidiary and transfer of knowledge may influence the balance of standardization and localization. The theories of Smale et al., (2013) regarding the attempt by MNCs to control the human resource management policies, practices and establish effective coordination of the policies and practices across their subsidiaries. Cray (1984) postulation that international integration occurs through two distinct processes, namely, control and coordination, may also by tested through empirical research.

To realize the true potential of automotive sector in the current theme of inclusive globalization, there is need to focus on systematic examination of IHRM practices surrounding automotive industry in the country; future research might provide invaluable theories and models, and validate the argument of (Sparrow et al., 2004; Legge, 2004) pointing that giving adequate importance to human resources in the organizations results in increased productivity and have a positive influence on the GDP of the country. 


\section{References}

Almond, F., \& Ferner, A. (2006). American Multinationals in Europe: Managing Employment Relations across National Borders. Oxford University Press, Oxford.

Alvesson, M., \& Berg, P. (1992). Corporate Culture and Organizational Symbolism. (Berlin: Walter De Gruyter).

Beardwell, I., \& Holden, L. (2001). Human Resource Management (3rd ed.). Pearson Education Limited.

Bélanger, J., Lévesque, C., Jalette, P., \& Murray, G. (2013). Discretion in employment relations policy among foreign-controlled multinationals in Canada. Human Relations, 66(3), 307-332.

Birkinshaw, J., \& Ridderstrale, J. (1999). Fighting of Corporate Immune System.

Boxall, P. (1995). Building the theory of comparative HRM. Human Resource Management Journal, 5(5).

Brewster, C., \& Harris, H. (2004). International HRM: Contemporary Issues in Europe. London: Routledge.

Buckley, P., Clegg, J., \& Tan, H. (2003). The Art of Knowledge Transfer: Secondary and Reverse Transfer in China's telecommunications Manufacturing Industry. Management International Review, 43, 67-93.

Caligiuri, P., \& Stroh, L.K. (1995). Multinational Corporation Management Strategies and International Human Resource Practices: Bringing International HR to the Bottom Line. International Journal of Human Resource Management, 6(3), 494-507.

Carpenter, M., Sanders, W., \& Gregerson, H. (2001). Bundling Human Capital with Organizational Context: The Impact of International Assignment Experience on Multinational Firm Performance and CEO Pay. Academy of Management Journal, 44.

Cray, D. (1984). Control and Coordination in MNCs. Journal of International Business Studies, 15(2).

Dohse, K., Jürgens, U., \& Malsch, T. (1985). From "Fordism" to "Toyotism? The social organization of the labor process in the Japanese automobile industry. Politics and Society, 14.

Dowling, P., Festing, M., \& Allen, D. (2013). International Human Resource Management (6th ed.), Thomson learning.

Ferner, A., Tregaskis, O, Edwards, P., \& Meyer, M. (2011).HRM structures and subsidiary discretion in foreign multinationals in the UK. International Journal of Human Resources, 22(3), 483-509.

Edwards, T., \& Almond, P. (2005). Reverse Diffusion in US Multinationals: Barriers from the American Business System. Journal of Management Studies, 42.

Festing, M., Eidem, J., \& Royer, S. (2007). Strategic Issues and Local Constraints in Transnational Compensation Strategies: An Analysis of Cultural, Institutional and Political Influences. European Management Journal.

Gunnigle, P., Murphy, K., Cleveland, J.N., Heraty, N., \& Morley, M.J. (2002). Localization in human resource management, comparing American and European multinational corporations. Advances in International Management, 14(1).

Gupta \& Govindarajan. (1991). Knowledge Flows and the Structure of Control within MNCs. Academy of Management Review, 16.

Harzing, A. (1999). Managing the Multinational: An International Study of Control Mechanism. Cheltenham: Edward Elgar.

Hofstede, G. (1980). Culture's Consequences: International Differences in Work-Related Values. Beverly Hill, Ca: Sage.

Huselid, M. A. (1995). The impact of HRM practices on turnover, productivity and financial Performance. Academy of Management Journal, 38(3).

Khilji, S. (2002). Modes of Convergence and Divergence: An Integrative View of Multinational Practices in Pakistan. International Journal of Human resource, 13.

Kiessling, T., \& Harvey, M. (2005). Strategic global HRM research in the twenty first century: An endorsement of the mixed-method research methodology. International Journal of Human Resource Management, 16(1).

Kim, K., Park, J. H., \& Prescott, J. E. (2003). The global integration of business functions: A study of multinational businesses in integrated global industries. Journal of International Business Studies, 34(4), 
327-344.

Klein, J. A. (1991). A reexamination of autonomy in light of new manufacturing practices. Human Relations, 44.

Kostova, T., \& Zaheer, S. (1999). Organizational Legitimacy under Conditions of Uncertainty: The Case of the Multinational Enterprise. Academy of Management Review, 24(1).

Kubo, I., \& Saka, A. (2002). An inquiry into the motivations of knowledge workers in the Japanese financial industry. Journal of Knowledge Management, 6(3), 262-271.

Legge, K. (2004). HRM: Rhetoric's and Realities. Anniversary, Basingstoke: Palgrave.

Lewchuk, W., \& Robertson, D. (1997). Production without empowerment: work reorganization from the perspective of motor vehicle workers. Capital and Class, 63.

Marquardt, M., \& Berger, N. O. (2003). The future: globalization and new roles for HRD. Advances in Developing Human Resources, 5(3).

Martinez, J. I., \& Jarillo, J. C. (1991). Coordination demands of international strategies. Journal of International Business Studies, 22(3), 429-444.

Mayrhofer, W., Brewster, C., Morley, M. J., \& Ledolter, J. (2011). Hearing a different drummer? Convergence of HRM in Europe - a longitudinal analysis. Human Resource Management Review, 21(1).

Meardi, G. (2004). Not Just a MNC's Paradise: Uncovering the Host Country Effects in Central Europe. Proceedings of the European Group on Organizational Studies Conference, Ljubljana, Slovenia, 1-4 July.

Michailova, S., \& Husted, K. (2003). Knowledge-Sharing Hostility in Russian Firms. California Management Review, 45(3).

Morgan, P. (1986). International Human Resource Management: Fact or Fiction. Personnel Administrator, 31(9).

Myloni, B., Harzing, A. W., \&Mirza, H. R. (2007). The effect of organisational factors on the transfer of human resource management practices: European and US MNCs and their Greek subsidiaries. The International Journal of Human Resource Management, 18(12), 2057-2074.

Ngo, H. Y., Turban, D., Lau, C., \& Siu, Y. (1998). Human Resource Practices and Firm Performance of Multinational Corporations: Influences of Country of Origin. International Journal of Human Resource Management, 9(4).

Nohria, N., \& Ghoshal, S. (1997). The Differentiated Network: Organizing Multinational Corporations for Value Creation. San Francisco, CA: Jossey-Bass.

Pietak, L. (2014). Review of Theories and Models of Economic Growth. Comparative Economic Research, 17.

Pieper, R. (1990). Human Resource Management: An International Comparison. Berlin: de Gruyter.

Pudelko, M. (2006). A comparison of HRM systems in the USA, Japan and Germany in their socio-economic context. Human Resource Management Journal, 16, 123-153.

Prahalad, C. K., \& Doz, Y. (1987). The Multinational Mission: Balancing Global Demands and Global Vision. New York: Free Press.

Rees, C. J., Jarualt, J., \& Metcalfe, B. D. (2005). Career management in transition: HRD themes from the Estonian Civil Service. Journal of European Industrial Training, 29(7).

Rosenzweig, P. M., \& Nohria, N. (1994).Influences on HRM Practices in MNCs'. Journal of International Business Studies, 25(2), 229-251.

Schuler. R., Dowling, P., \& Cicri, H. (1993). An Integrative Framework of Strategic International Human Resource Management. Journal of Management, 19(2).

Scott, W. (1995). Institution and Organization. Thousand Oaks, Ca: Sage.

Scullion, H. (2001). International Human Resource Management. In Strorey, J. (Ed,), Human Resource Management: A Critical Text. International Thompson, London

Sen, A. (1999). Development as Freedom. Oxford University Press

Smale, A., Björkman, I., \& Sumelius, J. (2013). Examining the differential use of global integration mechanisms across HRM practices: evidence from China. Journal of World Business, 48(2).

Sparrow, P., Brewster, C. \& Hillary, H. (2004). Globalizing Human Resource Management. Routledge London 


\section{and New York}

Sparrow, P., \& Marchington, M. (1998). Human Resource Management: The New Agenda. Financial Time Management: Knowledge, skills, understanding.

Taylor, S., Beechler, S. \& Napier, N. (1996). Towards an Integrative Model of Strategic International Human Resource Management. Academy of Management Review, 21.

United Nations Development Programme. (2006). New York, 10017, USA.

Whitley, R. (1992). Business Systems in East Asia. Manchester Business School, UK.

\section{Copyrights}

Copyright for this article is retained by the author(s), with first publication rights granted to the journal.

This is an open-access article distributed under the terms and conditions of the Creative Commons Attribution license (http://creativecommons.org/licenses/by/4.0/). 